\title{
ARTICLE \\ The Potential of Deweyan-Inspired Action ReseARCH
}

\author{
Jody L. Stark
}

\section{INTRODUCTION}

This article examines the potential of Action Research informed by Dewey's pragmatism as a research methodology in the social sciences. Not only a philosophical orientation, pragmatism is also a powerful mode of inquiry. When combined with the democratic research approach of Action Research, Deweyan pragmatism has great potential to shed light on educational and other social science questions, forward social change, and enact Dewey's vision of radical social democracy. Although Dewey's philosophy, one could argue, has never been mainstream in education and in research, the combination of Deweyan philosophy and Action Research has the potential to revive interest in Dewey's work and serve as an example of Deweyan inquiry.

This article is divided into three sections. In the first, I will provide an overview of both Action Research and pragmatism as a mode of inquiry, while in the second, I will outline a theoretical framework for Deweyan-inspired Action Research based on the scholarship of pragmatic action researchers Greenwood and Levin (2007), as well as Dewey. In the third section, I will address criticisms leveled at both Action Research and Dewey, and suggest that the combination of these two discourses/practices has great potential as transformative social science research.

\section{Action Research and Pragmatism as a Mode of Inquiry}

\section{Action Research: An Overview}

Although Action Research (AR) generally traces its roots to the work of GermanAmerican social psychologist Kurt Lewin (Adelman, 1993; Elliott, 1991), its development has not been a linear one. Greenwood and Levin (2007) describe several "strands" in AR history that have contributed to the "diversity of activities" of AR practice (p. 13). First, and significant in Lewin's story, is the Industrial Democracy Movement, an attempt to involve factory workers in participatory democracy to solve problems in their work environments. Also related to the principles of democracy, Greenwood and Levin's second strand encompasses a variety of forms of 
Action Research that all have for their aim equality, justice, and the end of oppression. Paulo Freire's work is important to this movement. The last thread is that of social science researchers concerned with finding a way to conduct human research that gives dignity and a voice to all participants. Greenwood and Levin call this tradition "Human Inquiry and Cooperative Inquiry" and cite Peter Reason, Hilary Bradbury, John Heron, and William R. Torbert as having been instrumental in the development of this strand.

These differing conceptions of AR have been informed by a variety of different philosophical discourses, including critical theory (Marx, Habermas), existentialism (Greene), hermeneutics (Gadamer), pragmatism (Dewey), and psychoanalytical theory (Freud). Noffke (2009) suggests that differing schools of Action Research foreground different dimensions, that is, either the professional, personal or political, although all Action Research is, by definition, political. As Carson writes, "Action research is rooted in a belief in the transformative possibilities of personal and collective action" (2009, p. 347). This is the action in Action Research. It is conceived of as a mechanism of social change grounded in principles of democracy (Greenwood and Levin, 2007). Action Research, then, is more than just a research methodology. It is an instrument of change to bring about transformation in people's lives wrought by the people themselves.

Pragmatism as Mode of Inquiry

Pragmatism has its roots in early 20th century America, most notably in the work of Charles Sanders Peirce (1839-1914), William James (1842-1920), and John Dewey (1859-1952) in a time when the ideas of Darwin and scientific inquiry were very much in vogue. Noteworthy is the fact that Action Research grounded in Industrial Democracy hails from the same historical moment and place as pragmatism. In fact, Adelman (1993) suggests that Lewin (1890-1947) was a "scientific pragmatist" (p. 12) and traces Lewin's Action Research methodology back to Peirce.

Although philosopher F. S. C. Schiller reportedly quipped that there are "as many pragmatisms as there are pragmatists" (Thayer, 1981, p. 5), in spite of the many differences among individual philosophers, all pragmatists are united in the belief that human existence inherently involves the active practice of making meaning through interaction with our environment (Almeder, 1986). What is "true" for the pragmatist comes not from Aristotelian first principles that exist "out there" separate from us, but from our experience of the world in which we participate. We come to truth through a process of continual adaptation to our environment, a process that is a lived form of the scientific method (Garrison, 1994). Ontologically, all beliefs are "subject to revision" therefore absolute truth does not exist (Almeder, p. 80). How we know something is true is that it fits with our current experience of the world. Almeder (1986), paraphrasing James, clarifies further: "it is not in the roots but the fruits of our beliefs that truth lies" (p. 81). Pragmatism, then, is both a theory of knowledge 
(Almeder, 1986) and a method of philosophizing (Thayer, 1981) which situates learning and knowing as active social practices of constructing and enacting truths, and sees the human condition as one of engaging in inquiry to continually make sense of the world, a view particularly suited to Action Research inquiry.

What are the consequences for research implicit in a pragmatic commitment? First and foremost, the consequence of pragmatism's revisionist ontology is that those who frame their work through the lens of pragmatism are not looking for "the Truth" but rather "what fits" for the situation (Almeder, 1986). Small " $t$ " truth is constructed through interaction with the environment, and, at least for the Deweyan scholar, is always viewed as being situated within what Dewey calls the "contextual whole" (Dewey, 1938b, p. 66). Thayer writes, "For Dewey, as for Peirce, inquiry is a process by which doubtful or unsettled situations become settled. The goal of inquiry is the attainment of belief; the product or outcome of competent inquiries is knowledge" (p. 171). Pragmatically-inspired inquiry, then, attempts to shine a light on a situation, experience, or phenomenon to clarify and "enlighten" towards a deeper and richer understanding. This is creating knowledge for the pragmatist.

For Dewey in particular, inquiry is a way of life-it is our way of being in the world. Dewey explained the process of inquiry as "the controlled or directed transformation of an indeterminate situation into one that is so determinate in its constituent distinctions and relations as to convert the elements of the original situation into a unified whole" (Dewey, 1938b, p. 104-5). Through pragmatism as a mode of inquiry, those involved in the research process are looking to fit new pieces into their current understanding about a given phenomenon. These pieces fall into place through a process of acting and observing in the research site, and then evaluating and making sense of the results towards a given goal. Meaning is clarified progressively by examining the consequences of actions and adjusting in a continual cycle of inquiry. In sum, Cherryholmes (1992) suggests that pragmatic inquiry

seeks to clarify meanings and looks to consequences. For the pragmaticallyinformed scholar, values and visions of human action and interaction precede a search for descriptions, theories, explanations, and narratives.

Pragmatic research is driven by 'anticipated consequences.' (p. 13)

Pragmatic inquiry, then, entails a progressive hermeneutic unfolding towards a deeper understanding.

\section{Action Research Informed by Pragmatism}

\section{Kurt Lewin and John Dewey: "A Striking Kinship"}

In its broadest sense, pragmatism could be said to be the philosophical orientation of all Action Research. ${ }^{2}$ Greenwood and Levin (2007) suggest that Action 
Research, regardless of approach, is informed by the belief that "there is no substitute for learning by doing" (p. 2). This characteristic of Action Research could be said to intersect with pragmatism's rejection of a dualist conception of theory and practice. For both Action Research and pragmatism, theory is seen as a tool or "instrument" that individuals use to make sense of the world of which they are a part. For pragmatists, to quote Garrison, "knowing is something that we literally do" (1994, p. 10).

Although Lewin and Dewey never met in person, there is no question that these two contemporaries had an enormous amount in common (Marrow, 1969). In fact, Allport (1948) suggested that "there is a striking kinship" between the two men's work (p. xi). Lewin was acutely interested in practical research to resolve discrimination and prejudice, and worked on projects to foster community involvement of citizens (Marrow, 1964). Like Dewey, he cared deeply about democracy. Dewey, who was at the height of his influence when Lewin came on the American scene, saw democracy as a social process requiring the involvement of all citizens and dependent upon open communication between social groups. Any barrier to participation in society or to communication between individuals or groups, such as racism, classism, and capitalist self-interest, was antithetical to his radical notion of democracy and needed to be eradicated (Robertson, 1992). Both men, in their own way, worked for the liberty and equality of all, conditions they viewed as necessary for democracy. Of the two, Allport (1948) wrote, "Dewey, we might say, is the outstanding philosophical exponent of democracy, Lewin its outstanding psychological exponent" (p. xi). Perhaps the similar ethos of their work can be explained by what Thayer (1981) calls "an incipient pragmatism (which infused) ... the whole fabric of American social experience" at the time when Lewin and Dewey were contemporaries (p. 7). In any case, it is not an exaggeration to say that the work and aims of these two scholars are extremely complementary. Both Lewin and Dewey were interested in improving social conditions, and both viewed knowledge as something that came from acting in the world.

In the following section, I will attempt to flesh out a theoretical framework for Action Research informed by Deweyan pragmatism, drawing on the work of Greenwood and Levin (2007) and Dewey.

\section{A Theoretical Framework for Deweyan Action Research}

Greenwood and Levin (2007) serve as a contemporary example of action researchers who explicitly use pragmatism as the epistemological foundation for their work. Looking at their framing of AR alongside key tenets of pragmatic philosophy will help us to get a sense for how pragmatism as a mode of inquiry could inform Action Research while outlining a theoretic framework for pragmatic AR. Because Greenwood and Levin state that they look to Dewey in their work, it is Dewey's "instrumentalism" that will serve for the purposes of this discussion (Dewey, 1938a). Of 
Dewey, Greenwood and Levin (2007) write, "John Dewey is particularly important for our exposition because his pragmatic philosophy laid out an action approach to science as a form of human inquiry and underscored its inherent connections to democracy in a way in concert with our views of AR" (p. 59). Dewey, then, is foundational for Greenwood and Levin.

The following proposed theoretical framework for pragmatic AR is based partly on Greenwood and Levin's (2007) work, and includes Deweyan notions of democracy, diversity, reflection, experience, and action.

\section{Social Democracy}

Deweyan-inspired Action Research has democracy as its central concern. Dewey wrote extensively on the topic of democracy as it relates to education and inquiry, and democracy was a subject that was important to Dewey throughout the body of his work. For Dewey, democracy depended on education as an instrument whose aim was to "[free] intelligence for independent effectiveness" (Dewey, 1903, p. 193). Dewey saw education as "the fundamental method of social progress and reform" on which democracy rested alongside the principle of freedom for all individuals (1929/1997, p. 22). Dewey's freedom was not just freedom from constraint. It was intellectual freedom: the ability to think reflectively rooted in the process of scientific inquiry, a capacity that was to be honed through education (Dewey, 1910/1997). For Dewey, this freeing of the intellect led not only to individual improvement, but also to social improvement, a primary aim of democracy which he saw as being created by the active engagement of reflective citizens.

Dewey believed that any social conflicts that arose in a community could be resolved democratically by applying intelligence to the situation, and that, through communication, commonality could be generated amongst people and various groups. Dewey's conception of democracy therefore depended upon communication. He saw free communication between groups as a way of generating common interests and beliefs, a process which Dewey felt had the potential for developing awareness of the impact of one's actions on the group as a whole. He viewed democracy as social rather than political in nature with the potential to be "the perfection of community life" (Robertson, 1992, p. 341). According to Garrison (1994), for Dewey, "social experience was social interaction" (p. 6, emphasis in original). Community life could be "educative" in the sense that living and communicating with others enhanced one's experience (Dewey, 1916).

Greenwood and Levin's (2007) pragmatic approach to Action Research aligns with Dewey's radical notion of democracy. Part of their stated goal for pragmatic Action Research is to increase social awareness of members of the group. They write,

AR is a research strategy that generates knowledge claims for the express purpose of taking action to promote social analysis and democratic social change.... AR aims to increase the ability of the involved community or 
organization members to control their own destinies more effectively and to keep improving their capacity to do so within a more sustainable and just environment. (p. 5, emphasis added)

Furthermore, Greenwood and Levin view the aim of AR as engendering freedom not only through increasing the self-efficacy of the members of the community, but also by examining and reconfiguring discourse and structural elements in order to allow for personal intellectual freedom to grow. Greenwood and Levin state that, "A central ethical and political goal in AR is to achieve liberating outcomes" (p. 135). This aspiration echoes Dewey's concern for the "liberation of the potentialities of members of a group in harmony with the interests and goods which are in common" (Dewey, 1927, p. 147). Individual freedom aligned with the common good is a key characteristic of Dewey's democratic ideal that is adopted here by Greenwood and Levin.

Greenwood and Levin (2007) also tap into Dewey's conception of democracy as a social phenomenon grounded in communication. For these authors, a commitment to radical social democracy underpins not only the aims of their work, but also their methodology. They write, "For us, the core element in pragmatic AR is the creation of arenas where discussion and collaborative research facilitate cogenerative learning" (p. 135). Like Dewey, Greenwood and Levin believe that democratic means are necessary to achieve democratic ends (Robertson, 1992).

Discussion, however, is not unique to Deweyan-inspired Action Research. It is possible to trace its use in AR back to Kurt Lewin's work, for example (Adelman, 1993). What can, perhaps, be traced to Dewey is that Greenwood and Levin are not proposing a framework to resolve conflict once and for all, but rather one that fosters a culture where a diversity of views and experiences can be heard and examined to further the resolution of problems that lead to improvement and freedom for the common good on an ongoing basis. This is Dewey's conception of democracy at work, which Greenwood and Levin frame as an "ongoing, collective process of social improvement" as opposed to a fixed state of affairs or an ideal off in the future (Greenwood and Levin, 2007, p. 60). For both Dewey and action researchers, democracy is a verb, so to speak.

Greenwood and Levin's framework for Action Research, like Dewey's philosophy, is instrumental in nature. Action research leads to the possibility of greater freedom of intellect (and person), which leads to a more just and democratic environment for the people in an AR site.

\section{Diversity}

As suggested above, a key idea implicit in Dewey's conception of democracy was diversity. For Dewey, democracy was not based on "majority rule," but rather on a process of consensus building beginning with the diversity of views and abilities of members of the community contributed for the benefit of all. For Dewey (1916), 
"diversity of stimulation means novelty, and novelty means challenge to thought" (p. 85). Challenge to thought provided openings for inquiry in that it potentially caused "a state of perplexity, hesitation, doubt" which was the impetus for reflective thought (Dewey, 1910/1997, p. 9). Diversity, then, was to be embraced. Rather than attempting to eradicate conflict, Dewey's conception of democracy used conflict to arrive dialectically at solutions that worked for the community in question (Greenwood and Levin, 2007).

Greenwood and Levin, as mentioned above, view Action Research primarily as a process of creating "arenas for dialogue," a view that is grounded in a Deweyan view of diversity (p. 135). For Greenwood and Levin, as for Dewey,

the diversity of skills, experiences, ethnicities, gender, and politics [are] the most valuable source of potential positive change in groups. We view these differences as a rich social resource, that, when effectively mobilized gives a group or an organization a much greater capacity to transform itself. (Greenwood \& Levin, 2007, p. 10-11)

Diversity is an important instrument for social change in Dewey's conception of democracy; therefore, it is a key component within a theoretical framework for Deweyan Action Research.

\section{Reflection and Experience}

Dewey saw reflection as a process of actively making sense of one's experience, and this sense-making as enabling people to plan for future action, or, in Dewey's terms, to "form a purpose." Dewey wrote,

We have to understand the significance of what we see, hear, and touch. This significance consists of the consequences that will result when what is seen is acted upon.... The formation of purpose is, then, a rather complex intellectual operation. It involves (1) observation of surrounding conditions; (2) knowledge of what has happened in similar situations in the past, a knowledge obtained partly by recollection and partly from the information, advice, and warning of those who have had a wider experience; and (3) judgment which puts together what is observed and what is recalled to see what they signify. A purpose differs from an original impulse and desire through its translation into a plan and method of action based upon foresight of the consequences of acting under given observed conditions in a certain way. (1938a, p. 68-69, emphasis in original)

Dewey saw experience as being central to education and inquiry, for it was one's experience that allowed one to interpret the significance of the information in front of oneself in a given situation at a given moment (Dewey, 1910/1997; 1938a). In fact, it was one's experience that brought about the question for inquiry and instigated reflection in the first place. ${ }^{3}$ As Greenwood and Levin (2007) suggest, 


\section{JODY L. STARK}

"(the) focus of (pragmatic AR) is determined by what the participants consider important, what affects their daily lives" (p. 63). Furthermore, because pragmatic AR values the experience of the participants over expert opinion, the results of a Deweyan Action Research inquiry are measured by the "orkability" or "fit" of the solutions generated. Whether or not an inquiry has resolved the issue at hand is "a matter of collective social judgment by knowledgeable participants about the outcomes of collective social action" (Greenwood \& Levin, p. 64). In other words, the evaluation of any inquiry is based on collective reflection.

Reflection, along with experience, is a central tenet of a framework for Deweyan inspired Action Research. Greenwood and Levin (2007) adeptly convey the importance of reflection to pragmatic AR: "With Dewey, we argue for understanding in inquiry as a process linking reflection and action in a unified process for the creation of new knowledge" (2007, p. 65).

\section{Action}

What should be apparent about Dewey's philosophy as identified in the quote above is that he saw both knowledge construction and, by extension, democracy as being rooted in action in the sense that understanding is actively constructed through (inter)action with/on one's environment. The individual in Dewey's epistemology is an active member of the inquiry group, acting on the environment, adjusting, reflecting, and acting again in a seamless and simultaneous process akin to Schön's (1983) conception of "thinking-in-action." As Greenwood and Levin (2007) point out, Dewey exhibited a "steadfast refusal to separate thought from action.... He believed that the only real sources of knowledge were to be found in action, not in arm chair speculation" (p. 60). Dewey's conception of action as intimately tied to thought and reflection stood in contrast to conventional dualist epistemology. Dewey saw thinking and action as inseparable parts of a dialectical process: "All people at the outset, and the majority of people probably all their lives, attain ordering of thought through ordering of action" (1910/1997, p. 41). And just as "ordering action" resulted in ordered thought, thought also served to order action: "Thought affords the sole method of escape from purely impulsive or purely routine action" (1910/1997, p. 14).

Greenwood and Levin unequivocally espouse a Deweyan epistemology in their framework for pragmatic Action Research, claiming that, "AR explicitly rejects the separation between thought and action that underlies the pure/applied distinction that (characterizes) social research" (p. 5). While this orientation towards action is clearly found in Action Research informed by other discourses, what makes a pragmatic action orientation unique is the dialectic relationship between action and reflection as well as the consequences of action.

For Dewey, action engendered ontological change. Garrison (1994) writes, "As Dewey saw it, we are participants in an unfinished universe rather than spectators 
of a finished universe. That is why our actions, our behaviors, our social constructions, deconstructions, and reconstructions have ontological significance" (p. 8). Engaging in pragmatic action research, therefore, also has ontological significance. It is not only the findings of an Action Research study that potentially incite change, but the very action of engaging in inquiry. For Dewey, inquiry (action + reflection) results in growth (Dewey, 1910/1997).

Dewey's orientation to action as a catalyst for growth and change coupled with reflective thought fits very well with Action Research's emphasis on action as research. For AR pioneer Kurt Lewin, there was "no action without research; no research without action” (in Marrow, 1969, p. 193).

\section{Conclusion}

The theoretical framework for Deweyan-inspired Action Research outlined above contains elements that are key to Dewey's philosophy of inquiry and social change. Dewey's radical notion of social democracy and its relationship with diversity, reflection, experience, and action form the basis of a framework for pragmatic AR. Pragmatic Action Research views democracy as a social process of building commonality, and democratic principles are not only the result of inquiry, they are viewed as guiding principles for conducting research. Diversity is a key stimulus for reflective thought, which is the driving force of Deweyan inquiry. All reflection is grounded in experience, as is any evaluation of the outcome of inquiry. Finally, reflection for Dewey is uniquely bound up with action. Theory comes from action, not the other way around, and the dialectical process of action and reflection results in growth and change.

We will now move on to a discussion of the potential of this form of inquiry in contributing to the landscape of social sciences research.

\section{The Potential of AR Informed by Pragmatism}

While it is somewhat difficult to separate Action Research in general with that of AR informed by Dewey's pragmatism, there is no question that pragmatically informed AR has great potential as a research framework. The last section of this paper deals specifically with several criticisms leveled at both Action Research and at Dewey, and suggests that pragmatic AR has unique strengths as a mode of inquiry that could overcome the identified weaknesses.

\section{Criticisms of Action Research}

Action Research has much to contribute to educational scholarship. Local stakeholders can attempt to forward their understanding of a problem in their school or school distinct, for example, and make changes that positively impact the educational experience of students and the school environment. Not only can Action Research be effective, it has the potential to empower teachers, students, administrators, and parents, in part because they are involved in the process of inquiry from 
the ground floor up, and in part because participants often have the opportunity to see their impact on a situation as the project unfolds.

Due to the fact that participants are involved in all aspects of an action research study from determining the question to deciding on and enacting plans, action research is a challenge to the hierarchical epistemology of positivist research practices. This is a significant strength of Action Research methodologies. Another notable strength is the fact that Action Research is also an ethical challenge in which "all participants share the perquisites of privilege ... local stakeholders are the only extant experts on local culture, beliefs, and practices and because moral considerations require that local perspectives be honored" (Stringer, 2007, p. xii). AR relies on participant knowledge to inform research practice and considers practitioner knowledge as "knowledge that counts." This democratic commitment at the outset holds great potential for knowledge generation and empowerment of the people involved in the research process, ${ }^{4}$ a valuable benefit for participants and researchers alike. As we have seen, this commitment also aligns with Dewey's pragmatism in the sense that for Dewey, democracy is not only the aim of inquiry, "it is the best way to do research" (Garrison, 1994, p. 10).

In spite of this strong focus on ethical and democratic principles, some scholars raise concerns that Action Research does not deliver as promised, often failing to result in substantial change (for example, Kinchloe, 2003; Lather, 1986). This is one of my biggest concerns personally about Action Research as a methodology. Because of its emphasis on action and generating "desired and tangible results for the people involved," I fear that action researchers might tend to focus primarily on external factors and measures when problematizing, planning for change, and evaluating (Greenwood \& Levin, p. 51). Like Carson (2009), I strongly believe that any inquiry whose aim is transformation must address the identities of those involved both in the study and around the study. In my experience, change rarely happens unless the people involved change.

Another concern raised in the literature about Action Research is that it has been co-opted by those in power to be a tool of what Schön (1983) refers to as "technical rationality." Action Research, when co-opted, becomes one more way of forwarding the agenda of those in power, as opposed to opening spaces for true dialogue in a way that respects the diversity of those involved in the research (Elliott in Kinchloe, 2003). I am suggesting that the combination of pragmatism and Action Research may strengthen Action Research as a methodology and lessen or counteract these flaws in several ways.

First, a pragmatic orientation to AR makes it possible to engage in dialogue that, in Dewey's words, "throws into relief the possibilities of the future" (1929/1997, p. 154). The possibility for a truly "democratic" process of inquiry, which rejects consensus models of democracy and distributive justice, is unique and potentially powerful (Greenwood \& Levin, 2007). AR grounded in Dewey's epistemology could 
promote dialogue in a maieutic sense as opposed to engendering debate, and therefore it has the potential in the right hands to facilitate building profound respect and understanding among participants.

Secondly, the combination of Dewey's pragmatic framing of scientific thinking as being a process of "disentangling" and making meaning, pragmatic ontological commitments, and Dewey's radical social democracy seems to open the door to the potential of truly honoring the diversity of participants in an Action Research study and affirming their knowledge (Dewey, 1929/1997, p.152). This affirmation of participants may in turn lead to a deeper understanding of the situation to be changed, and lead also to deeper "buy-in" of participants. Furthermore, Dewey's democratic process of building commonality from diversity and the uniting of reflective thought and action in Dewey's philosophy have the potential to lead to ontological change in the participants. Situations are more likely to change if the people involved change.

\section{Criticisms of Dewey}

After discussing some important concerns about Action Research and suggesting that a pragmatic framework for AR could potentially lessen these weaknesses, I will now turn to criticisms of Dewey's work.

A common critique of Dewey is that he was naive about either people's ability to use intelligence to solve social problems, or the goodness of their nature (Robertson, 1992); those that make these charges often suggest that Dewey's social theory relied on a belief in democracy and human intelligence akin to religious faith (Campbell, 1987). In defense of Dewey, Campbell (1987) asserts that Dewey did not believe that intelligence was a panacea for all social problems, just that it had a better chance of success than the alternatives.

Others have suggested that pragmatism does not acknowledge the impact of embedded structural power on a community's ability to solve problems (Mills, 1969; White, 2004). Here, too, we see a different variation of the accusation that a pragmatic conception of democracy is based on unfounded faith. In defense of Dewey, Midtgarden (2012) contends that Dewey was not, in fact, indifferent to issues of power, arguing instead that, "Dewey's social philosophy confronts the issue of domination and power on a broad scale" (p. 507). Midtgarden maintains that Dewey's critics have not looked closely at Dewey's writings on social philosophy in which he takes a historical approach, "(extending) his social criticism to the cultural sources of normative authority or 'the authority of tradition"' (p. 508). ${ }^{5}$

Although Midtgarden adeptly makes the case that Dewey acknowledges the difficulties of power and authority in affecting social change, he does not address the criticism that Dewey's philosophy is based on naïve faith in democracy and in people. In response to this accusation, McDermott (1984) suggested that the question for pragmatists is not a matter of faith, but rather one of hope. McDermott writes, 
We have no guarantee that any of this will go well, although it is well worth attempting. Put differently, neither optimism nor pessimism seems to be a proper response, for each approach neglects the data generated by the other. (p. 673)

A Deweyan framework for AR, then, is ultimately based on hope. In the face of problematic social issues, average people in their communities can attempt change in the hope of bettering their situation. This approach may not always seem realistic to the outsider, but it is empowering. The individual and the community are assumed to be capable and agentic, and the situation is viewed as hopeful. AR informed by pragmatism does not demand that the project succeed in a final way or even that it be realistic in terms of the long view, just that it forward understanding and change the situation in some way for the better. In fact, deepening understanding is success for pragmatic inquiry. McDermott (1984) says it well when he submits,

At bottom, pragmatic epistemology is an attitude; one that does not make truth announcements, let alone pronouncements or manifestoes, but rather is ... an experimental probing. ... Pragmatism has an inductive temper, yet it is far more aware of possible novelty and it is willing to treat ideas as explorers, ferreting out new ground on which to stand, even at the risk of being severely wrong. It was Dewey who stressed that error and failure, if properly respected, are often profound sources of insight. (p. 669)

Dewey was not at all naïve. He knew that any process of inquiry could and would at times result in errors, but if continually revising one's understanding through reflection, those same errors could be a source of new understanding. He also knew that growth and change were rooted in difficulty (Dewey, 1938) ${ }^{6}$ and that difficulty (power, authority) was inherent in society.

Although some might scoff at the idea of research being prefaced with hope, I believe hope is a fine place to begin an inquiry, for what is the point of any research if it is not undertaken with the hope that one will be able to add to human understanding and improve the situation of those around us?

\section{CONCLUSION}

Action Research and Dewey's pragmatism have many commonalities that create great potential for research and social change when combined. Most notable among their similarities include a foundation in radical democracy and a belief that democracy is not only the desired outcome of inquiry, but the best method for research. The combination of Action Research's practice of inciting understanding through action, which aligns with Dewey's conception of activity, and a Deweyan emphasis on communication, diversity, and an ever-evolving ontology amount to a powerful tool for inquiry in the social sciences. Furthermore, both of these traditions reject a dualistic perspective on experience and knowledge, 
and turn the traditional relationship of theory and practice on its head (Stringer, 2007). Robertson (1992) claims that Dewey's philosophy has never been mainstream, but I am suggesting that perhaps it should be when it comes to praxial educational research.

Pragmatically-informed Action Research is praxial in nature. It is driven by a concern for action in general and "right action" in particular. In this sense, it embodies the spirit of critical inquiry. Kinchloe (2003) suggests that critical inquiry must be "counter-Cartesian," requires self-reflection, and embodies democratic principles (p. 54), all foundational orientations of Deweyan-inspired Action Research.

Lather (1986) argues that a strength of critical Action Research is that it is unlikely to be subverted by those in power and reduced to being a tool of "practitioner improvement," rather than being an instrument of social transformation. This is a significant strength of pragmatic Action Research as a mode of inquiry. In spite of the criticisms leveled against Dewey, Action Research combined with Dewey's social democracy has the potential to inoculate against power imbalances.

Not only is pragmatic AR critical inquiry, it is also what Greene (1986) has called a "critical pedagogy" in the sense that it is concerned with the growth of those involved in the research. Greene suggests that critical pedagogies work to "find out how to open such spheres, such spaces, where a better state of things can be imagined; because it is only through the projection of a better social order that we can perceive the gaps in what exists and try to transform and repair" (p. 441). This is the potential and hope of Action Research informed by Deweyan pragmatism.

\section{REFERENCES}

Adelman, C. (1993). Kurt Lewin and the origins of action research. Educational Action Research, 1(1), 7-24.

Allport, G. W. (1948). Foreword. In K. Lewin, Resolving social conflicts: Selected papers on group dynamics. New York, NY: Harper \& Row.

Almeder, R. (1986). A definition of pragmatism. History of Philosophy Quarterly, 3(1), 79-87. http://www.jstor.org/stable/27743755

Campbell, J. (1987). Optimism, meliorism, faith. History of Philosophy Quarterly, 4, 93-113.

Carr, W. \& Kemmis, S. (1986). Becoming critical: Education, knowledge, and action research. Philadelphia, PA: Falmer Press.

Carson, T. (2009). Teaching and cultural difference: Exploring the potential for a psychoanalytically informed action research. In S. Noffke \& B. Somekh (Eds.), The Sage handbook of educational action research (pp. 347-357). Thousand Oaks, CA: Sage Publications.

Cherryholmes, C. (1992). Notes on pragmatism and scientific realism. Educational Researcher, 21(6), 13-17. http://www.jstor.org/stable/1176502

Dewey, J. (1903). Democracy in education. The Elementary School Teacher, 4(4), 193-204. 
. (1910/1997) How we think. Retrieved from http://www.brocku.ca/MeadProject /Dewey/Dewey_1910a/Dewey_1910_a.html

- - - (1916). Democracy and education. New York, NY: MacMillan

-_- . (1927). The public and its problems. London: Allen.

. (1929/1997). My pedagogical creed. In D. Flinders \& S. Thorton (Eds.), The curriculum studies reader, (pp. 17-23). New York, NY: Routledge.

-_- (1938a/1997). Experience and education. New York, NY: Collier MacMillan.

_-_. (1938b). Logic: The theory of inquiry. New York, NY: Holt, Reinhart, and Winston.

-_- (1960). The quest for certainty: A study of the relation of knowledge and action-Gifford Lectures 1929. New York, NY: Putnam.

_-_. (1973). Lectures in China, 1919-1920. Honolulu, HI: The University of Honolulu Press.

Elliott, J. (1978). What is action-research in schools? Journal of Curriculum Studies, 10(4), 355-357. http://dx.doi.org/10.1080/0022027780100407

-_- . (1991). A practical guide to action research. Action research for educational change. Philadelphia, PA: Open University Press, 69-89.

Feldman, A. (2002). Existential approaches to action research. Educational Action Research, 10(2), 233-251.

Garrison, J. (1994). Realism, Deweyan pragmatism, and educational research. Educational Research, 23(5), 5-14. http://dx.doi.org10.3102/0013189X023001005

Greene, M. (1986). In search of a critical pedagogy. Harvard Educational Review, $56,427-441$.

Greenwood, D. \& Levin, M. (2007) Introduction to action research (2nd ed.). Thousand Oaks, CA: Sage Publications.

Kadlec, A. (2007). Dewey's critical pragmatism. Lanham, MD: Lexington Books.

Kinchloe, J. L. (2003). Teachers as researchers: Qualitative inquiry as a path to empowerment. New York, NY: Routledge Falmer.

Lather, P. (1986). Research as praxis. Harvard Educational Review, 56(3), 257-278.

Lewin, K. (1946). Action research and minority problems. Journal of Social Issues, 2(4), 32-36.

Marrow, A. J. (1964). Kurt Lewin Memorial Award address: Risks and uncertainties in action research. Paper presented at the Society for the Psychological Study of Social Issues at the American Psychological Association Convention, Los Angeles, California. September 5, 1964.

-_- . (1969). The practical theorist: The life and work of Kurt Lewin. New York, NY: Basic Books.

McDermott, J. J. (1984). Classical American philosophy: A reflective bequest to the twenty-first century. The Journal of Philosophy, 81(11), 663-675.

Mills, C. W. (1969). Sociology and pragmatism: The higher learning in America. New York, NY: Oxford University Press. 


\section{The Potential of Deweyan-Inspired Action Research 101}

Midtgarden, T. (2012). Critical Pragmatism: Dewey's social philosophy revisited. European Journal of Social Theory, 15(4), 505-521. http://dx.doi.org/10.1177 /1368431011432373

Noffke, S. (2009). Revisiting the professional, personal, and political dimensions of action research. In S. Noffke \& B. Somekh, (Eds.), The Sage handbook of educational action research (pp.6-23). Thousand Oaks, CA: Sage Publications.

Robertson, E. (1992). Is Dewey's educational vision still viable? Review of Research in Education, 18, 335-381.

Schön, D. (1983). The reflective practitioner: How professionals think in action. New York, NY: Basic Books.

Smits, H. (1999). Living within the space of practice: Action research inspired by hermeneutics. In T. Carson and D. Sumara, (Eds.), Action research as a living practice (pp. 281-297). New York, NY: Peter Lang.

Stringer, E. (2007). Action research ( $3^{\text {rd }}$ ed.). Thousand Oaks, CA: Sage.

Thayer, H. S. (1981). Meaning and action: A critical history of pragmatism. Indianapolis, IN: Hacket Publishing Company.

White, S. K. (2004). The very idea of a critical social science: a pragmatist turn. In: Rush F (Ed.), Cambridge companion to critical theory. Cambridge: Cambridge University Press.

\section{NOTES}

1. See chapters 7 and 8, Dewey, J. (1910). How we think. Boston, MA: D. C. Heath for a discussion of thought and belief.

2. In fact, the pragmatic inquiry process described above has many similarities with Lewin's (1946) Action Research spirals, as well as with the AR models of later generations of action researchers (Ex. Elliott, 1978; Carr \& Kemmis, 1986).

3. See "How We Think" chapter 6 for a discussion of the relationship between experience and inquiry.

4. I especially see its usefulness in working with teachers in school settings, and draw the reader's attention to the large amount of scholarship that suggests AR as a useful strategy for professional growth of teachers.

5. Midtgarden relies heavily on Dewey's (1973) "Lectures in China" as the basis of his argument.

6. "Nonetheless, growth depends upon the presence of difficulty to be overcome by the exercise of intelligence" (Dewey, 1938a, p. 79).

Jody Stark is a Ph.D. student at the University of Alberta and a lecturer at Concordia University College of Alberta in Edmonton, Canada. Email: jlstark@ualberta.ca. 